\title{
NARRATIVE AS A COMMON TECHNIQUE OF SELF-INTERPRETATION
}

\author{
Johann Michel ${ }^{1}$ \\ (Université de Poitiers / Institut Universitaire de France \\ and researcher at EHESS)
}

The narrative thread in this paper is a reflection on what we could call the dual nature of the act of interpreting: interpretation seen both from a methodological and epistemological perspective (the place of interpretation in the humanities, or even in the natural sciences) and also from an anthropological perspective (the place of interpretation in the ordinary activities of the everyday life). The first perspective generally belongs to a philosophical tradition associated with methodological hermeneutics, from Schleiermacher to Dilthey and Ricœur: the aim being to ground the humanities on the basis of understanding, in place of the explanatory model advocated, in particular, by the positivist tradition.

It is not this first perspective that we want to address in this article, but the second, which centers specifically on a social and philosophical anthropology of human being as an interpreting being. The purpose is to analyze interpretation as a "common" technique (by contrast with the academic, professional, philosophical and scientific techniques that Michel Foucault bundles together under the label of technologies of the self ${ }^{2}$ ), a technique for relating to the world and to oneself at times when individuals or groups are confronted with difficult situations or with traumatic or life-changing events. Narration, in particular, is a common technique of

\footnotetext{
1 johann.michel@ehess.fr

2 Michel Foucault, L'Herméneutique du sujet, Paris: Gallimard, 2001.
}

Philosophica, 51, Lisboa, 2018, pp. 65-79. 
interpretation used by individuals and groups seeking to inscribe shocking events into the story of their lives.

Firstly, we will raise the question of when self-interpretation occurs, and what makes Man, in Charles Taylor's words, "a self-interpreting animal"3. Secondly, we will show why narration can be seen as a particular modality of self-interpretation that we call ethno-interpretation. Finally, we will argue that self-interpretation-far from being evidence for the existence of a sovereign consciousness - presupposes social and cultural conditions of possibility.

\section{Interpretation and the problematicity of meaning}

What is interpretation? Clearly, it refers to a mode of understanding in which the intended object is relatively indeterminate (an image, a text, a trace, an action, a sign, a situation); it is, in any case, an understanding that resists any immediate grasping of the meaning of something. Interpretation is a mediate or mediated understanding where the meaning does not spontaneously make itself intelligible. Interpretation - and this is what gives it its reflexive, suspensive dimension - then takes the form of a search or inquiry. Under these conditions, interpretation is indeed peculiar to mankind, even if human beings, as they go about their business, are not constantly interpreting everything just because they happen to be semiotic animals that dwell in a world of meaning and symbols. We interpret something when we do not understand it. It is the correlated phenomena of the absence of meaning, the confusion of meaning and the "problematicity of meaning" that call for an "inquiry" into meaning. Of course, there is no clear dividing line between immediate understanding and interpretive understanding: there are plenty of gray areas, plenty of variation between the clear and the unclear, the obvious and the obscure, the familiar and the foreign, the straightforward and the problematic.

One could easily get the impression, from all of these examples, that interpretation only really applies to strictly intellectual, artistic, philosophical or scientific activities. Look no further than what the academic literature or the philosophy manuals have to say about interpretation, which they treat as an offshoot of a theory of knowledge: Are all interpretations equally valid? Is everything a matter of interpretation? Are there no objective facts? But if we venture the hypothesis that interpretation is

3 Charles Taylor, Sources of the Self, Harvard: Harvard University Press, 1992. 
one of the highest functions of the human condition in the symbolization process, then it is characteristic of the man in the street as well as the man of science.

Heidegger's hermeneutic phenomenology ${ }^{4}$ offers interesting ways of thinking about the phenomenon of interpretation. It is not simply a question of describing the original understanding of factic life, but of worrying about the fallenness of a life embedded in everyday life, which is both reassured and alienated. But why is interpretation necessary? Certainly, because the Dasein gravitates around the universe of meaning, but above all because the sense of the being of Dasein is problematic. Hermeneutics thus has the task of making each Dasein attentive to its own being and arousing a radical awakening of itself. The human being becomes properly interpreting when, from the depths of this familiarity, something foreign happens in the world. Concern is placed on alert; temporality comes off its hinges; common space becomes foreign.

The heideggerian "hermeneutic reversal", however, is not without limitations. It can be a useful way of rethinking the processes of self-interpretation when confronted with anxiety about the meaning of existence and the strangeness that occurs in the surrounding world. However, this extension of hermeneutics, in the ontological direction is still too narrow to hope to build an interpretative anthropology. It is because the problematicity of the sense of Dasein is indexed each time to registers of authenticity and inauthenticity of existence, which ultimately deny all significance to any interpretation not directed toward the meaning of my existence, my own death, or the forgetfulness of being.

Only an anthropology of homo interpretans tells us precisely about all of the ordinary techniques used by men and women to cope with the opacity of the signifying world, or with traumatic events. They consequently employ ordinary methods that we might call "ethnomethods" to handle the obscurity or problematicity of meaning (Patočka). The Heretical Essays invite us to think about the historical conditions of interpretation. The Czech phenomenologist's concise, dense writing provides a useful framework for thinking about the "problematicity of meaning", in the telling phrase that he coined. The heart of the philosopher's approach lies in the slant he gives to the Husserlian thesis of the "natural world", which is no longer simply assimilated to the "pre-scientific world" (as is the case in Krisis) but to the "prehistoric world", in a specific sense, far removed

\footnotetext{
4 M. Heidegger, Etre et temps, Paris: Gallimard, 1992.

5 Jan Patočka, Essais hérétiques, Paris: Verdier, 1990.
} 
from the historiographical notion of prehistory. Paradoxically, the prehistoric world, as envisaged by Patočka, is not bereft of myths, stories and histories. Quite the contrary: these narrative forms serve to keep mankind within the prehistoric, i.e. within a life-sustaining social cycle, transmitting and receiving worlds of meaning that are never really questioned. The prehistoric world, as a natural world, is fundamentally a "non-problematic" world: "life simply as it is contained in the self-evidence of received meaning, in the traditional way of life, its forms and modes (...)."

This description offers a powerful illustration of the process by which meaning is naturalized, though it could be criticized for its historicism, evident in the way the "historic world" is defined. With perfect consistency, the historic world is characterized by the "problematicity of meaning": history begins when human being stops accepting the meaning transmitted by tradition; history begins when, as meaning is denaturalized, human being goes in quest of new meaning; history begins, ultimately, when the human being starts interpreting. For Patočka, in other words, interpretation, in the strictest sense, is by no means a universal anthropological disposition-it is a contingent historical possibility.

The proof is that history, for Patočka, really only begins with Greek civilization, which suspends and challenges the political, cosmological and natural order. It is with the Greeks that the great denaturalization of meaning takes root. Such is the legacy of the "problematicity of meaning" to the very foundations of European civilization. By contrast, the other civilizations (if we can still call them that) - those that preceded "the Greek miracle" or have not yet been directly affected by its influence - are relegated to the prehistoric world.

Without disputing the existence of the "Greek miracle", it is surely a fair bet that Patočka's eurocentrism would not stand up to more detailed research on the historical anthropology of non-European civilizations. The confusion stems, in fact, from the status accorded to the "problematicity of meaning" correlated with the "historic world". When Patočka describes the world as problematic, he has in mind a meaning that is more philosophical than anthropological, and in a register that is more meta-interpretive than interpretive. The problematicity of meaning, from the philosopher's perspective, concerns the totality of what is, i.e. "the whole of existence".

And yet the notion of the problematicity of meaning can be given a much broader conceptual status: an anthropological and social status. In this context, the problematicity of meaning as expressed by Patočka is just

${ }^{6} \quad$ Ibid., p. 14. 
one variant of interpretation, and a radicalized one at that, not only because it concerns the whole of what is, but because it is presented in a philosophical mode, i.e. in a meta-interpretive register. The problematicity of meaning takes on a much wider scope, however, if it is seen as an ordinary human activity when confronted with anything that disrupts the orderly flow of the immediate understanding of meaning, without precluding the possibility of questioning. The notion of "problematicity of meaning" can then be decontextualized from the framework of the philosophy of history, in which Patočka was still working, and recontextualized into the framework of the sociology and anthropology of ordinary activities. ${ }^{7}$ One can then speak of an ordinary epoché-which is not that of the phenomenologists, and does not have the same ambition - when groups and individuals question their own judgment about whether the meaning of a behavior, a situation, or an utterance is "natural", in so far as that meaning has ceased to be self-evident.

The expression "prehistoric world" can then be replaced by "ordinary epoché" or by G.H. Mead's "immediate experience". ${ }^{8}$ Mead uses the term immediate experience to refer to a relationship with the world that proceeds without problems, without conflicts, without tensions, when the responses of individuals or groups are adapted to the situations of their environment. But when unprecedented events occur in "the world that is there", when the environment undergoes changes, when elements of doubt or uncertainty creep in, immediate responses are not enough. A certain attitude is required, which Mead calls cognitive thought and Dewey calls inquiry $^{9}$, if we are to adjust our responses to a new environment, and reassure ourselves about the existence of objects and about the value and meaning of things.

This interpretive process is dual-faceted: one facet is a form of $u n-$ dergoing, where the individual or group experiences a "disruption", in Dewey's sense, of its immediate understanding of the meaning of just such a denaturalized situation - in other words, the suspensive and reflexive attitude - the other facet is a form of doing, or "inquiry", when agents go in search of a new meaning better suited to the understanding of a situation, when they try to establish new relations of meaning between strange or

\footnotetext{
7 Louis Quéré \& Cédric Terzi, "Pour une sociologie pragmatiste de l'expérience publique", SociologieS [online], Dossiers, Pragmatisme et sciences sociales: explorations, enquêtes, expérimentations, online since 23 Feb (2015), consulted 12 Jan 2016. URL: http:// sociologies.revues.org/4949

8 George Herbert Mead, Mind, Self, and Society, Chicago: University of Chicago Press, 2015.

9 John Dewey, Logic, Theory of Inquiry, NYC: Read Books, 2007.
} 
unknown phenomena, or when they resolve ambiguities about the meaning of a text or conversation. There is nothing to say when, if ever, this circling around meaning will come to an end, given that any new occurrence of a strange meaning is liable to once again trigger the process of inquiry and the interpretive journey to adjust the response to the environment.

In this pragmatist framework, the hypothesis of the universality of Homo interpretans can be defended. In other words, whatever culture or civilization they belong to, people can experience the strangeness of the proffered meaning (of an action, utterance, text, etc.), without necessarily having to question (scientifically or philosophically) the totality of what is, or the general order of things. Even in what Patočka would call "prehistoric" societies, traditions of meaning are never received passively; they are interpreted so as to re-inscribe them in the next generation, to compare them with other traditions of meaning, or to cope with upheavals in the cycles of life. The symbolic worlds of human societies are never entirely fixed and intemporal, even in the societies that least resemble our own.

This brings us back to the ordinary interpretations that can be called ethno-interpretations, to designate the type of ordinary interpretive techniques employed to cope with unfamiliar, atypical situations (as opposed to typical ways of doing things - often the preferred focus of ethnomethodology - such as the routine situations of daily life). These ethno-interpretations are employed precisely in order to overcome situations where meaning is problematic. They differ from professional techniques of interpretation and self-interpretation in two ways: because they depend on ordinary know-how and ways of seeing (which are not the techniques devised by exegetes, philologists, psychoanalysts, etc.) and because they do not seek to suspend the meaning of the whole of Being.

\section{Narration as ethno-interpretation}

Ordinary life is a patchwork of micro-distortions of meaning that have none of the radicality of Cartesian doubt or of the Husserlian epoché. Of all the ethno-interpretations that we could identify (clarification, simplification, explicitation, translation, unveiling, symbolization, etc.) one in particular plays a key role in the process of self-interpretation: narration. It must be stressed, however, that ethno-interpretations such as narration can in no way be reduced simply to the reflexive relationship of self to self (which is just one particular form). Narrating an unexpected event that happened at work is one thing; recounting the impact of a life-changing 
event or series of events is something else altogether. Such events can be called biographical events.

An occurrence, in the sense of something that happens, becomes a biographical event when it has a deep and lasting impact on the meaning that an individual gives to his or her existence, when it reshapes the overall history of past experience, present existence and future projections. Unlike simple occurrences, biographical events "sometimes become meaningful only when seen in retrospect, in relation to the bigger picture, or to a later event. ${ }^{10}$ " Whence the importance of distinguishing, as Claude Romano suggests, ${ }^{11}$ between events and facts. Whereas a fact is characterized by its reproducibility and its predictability, an event disrupts the order of meaning of our expectations. We should draw a distinction, however, as does the sociologist Michel Grossetti, between events that have a relatively low share of unpredictability and a relatively high degree of reversibility (such as high-school leavers entering the job market), and events that are relatively unpredictable and highly irreversible (such as being suddenly afflicted by an incurable illness). For this last category of events, Grossetti reserves the term "bifurcation", to convey the greatest weight that can be given to the notion of biographical event. ${ }^{12}$

The work of self-interpretation can only take place - if it takes place at all - at a later point in time, i.e. when the event is amenable to a reflexive reworking of meaning, which is inseparable from an operation of "emplotting" (building a narrative) is the sense of narrative identity ${ }^{13}$. Claude Romano is already pointing the way to such a linkage when he demonstrates that events only happen retrospectively. Paradoxically, the meaning of an event is never entirely realized in the present. ${ }^{14}$ The event modifies our relationship to time, and the interplay of different timeframes. Because events acquire their significance only in retrospect, it is in narrative plots that meaning can be generated. To speak of a biographical event as life-changing, as a "bifurcation of existence", as a "reversal of fortune" in the sense of Aristotle, or as redefining one's expectations supposes two things: firstly, that it can be compared with other events, and with the

\footnotetext{
10 M. Leclerc-Olive, Le dire de l'événement, Lille: Presses du Septentrion, 1997, p. 34.

11 C. Romano, L'événement et le monde, Paris: PUF, 1999 and L'aventure temporelle, Paris: PUF, 2010.

12 M. Grossetti, Sociologie de l'imprévisible. Dynamiques de l'activité et des formes sociales, Paris: PUF, 2004.

13 P. Ricœur, Soi-même comme un autre, Paris: Seuil, 1990.

14 C. Romano, L'aventure temporelle, op. cit., p. 79.
} 
regular routine of life, and secondly, that it can be embedded in the context of a life story. By definition, a biographical event cannot have meaning by reference to itself. For there to be an event, a bifurcation, or a turning point, there must be at least two "points in time". ${ }^{15}$ A biographical event may itself be composed of a series of events of indeterminate length (already providing a potential plot). Living through war, a career change, or a relationship break-up - and one can think of many other examples - is not experienced as a biographical event only at the moment when such events first affect the subject. More often, these events only acquire biographical significance over time. But however long it takes is irrelevant, unless the subject is able to weave a plot, i.e. to arrange and rearrange the meaning of events relative to each other; in other words, to tell a story.

When a biographical event allows meaning to be reassessed as part of a process of self-interpretation, this is a form of biographical work ("putting life back together") as defined by Anselm Strauss ${ }^{16}$ i.e. re-configuring the meaning of past existence by telling new stories about oneself. Biographical work is therefore indissociable from self-oriented narrative work: where the biographical event creates discontinuity, sometimes radical discontinuity (as with Strauss's chronically ill subjects), between a "before" self and an "after" self, narrative work, as a particular self-technology, helps to restore biographical continuity. Biographical work-like, in many cases, the work of mourning - is never completely finished, just as narrative identities are constantly being made and unmade. Shaken by a biographical rupture, the subject may struggle to find a new plot for an event so upsetting that it modifies his previous self-narrative, especially when his previous life was lived in a naturalized mode. As Michael Pollak wrote, in the same vein: "identity only becomes a concern and, indirectly, an object of analysis, when it can no longer be taken for granted, when the common meaning is no longer given in advance, and the actors present can no longer agree on the significance of the situation or the roles they are supposed to play". ${ }^{17}$

Whence the existence of narrative configurations that are incoherent, incomplete and unstructured, where the event simply doesn't seem

15 On the notion of turning points as events that "set us on a new path" as opposed to the regular cycles of life, see E.C. Hughes, "Cycles, Turning Points and Careers", The Sociological Eye, Aldine, Chicago (1971) pp. 124-131 and A. Abbot, "From Causes to Events", Sociological Methods and Research, 20, pp. 428-455.

16 A. Strauss, La Trame de la négociation, Paris: L'Harmattan, 1991.

17 M. Pollak, L'Expérience concentrationnaire. Essai sur le maintien de l'identité sociale, Paris: Métailié, 2000, p. 10. 
to fit in with the life story seen as an ordered whole and understood as a "synthesis of the heterogeneous" (goals, reasons, happenstances, etc.) That is why we should not be too quick to judge whether attempts at "self-emplotment" are "well-constructed" in terms of the narrative rules inherited from the Aristotelian schema. This is probably the weak point in Ricœur's conceptualization of narrative identity, which relegates all such scraps of narrative - any tales that are incoherent, dechronologized, or that have no end or even no defined beginning - to "pre-narrative experience". ${ }^{18}$

Who am I? A narrative, says Ricoeur ${ }^{19}$. But not any narrative: it is a narrative confronted by the aristotelian model of muthos. In other words, the subject can not construct the meaning of his existence without a principle of narrative concordance through all the vicissitudes of his existence. But, daily life is a mish-mash of sub-plots that could never be described as "well-structured". The model of emplotment preferred by Ricœur (the muthos) is, ultimately, just a particular form of narrativity. ${ }^{20}$ "Blocked narratives" are, in fact, a way of thinking about biographical events so traumatic and emotionally charged that they prevent the individual from saying the event.

These extreme experiences impede the process of self-interpretation as a form of biographical work and a way of narrativizing one's own story. While there is no self-interpretation without first suffering a disruption of meaning (the undergoing facet), not every crisis or rupture of meaning necessarily leads to a reflexive appropriation of meaning in a new emplotment (the doing facet). Narrative self-interpretation is only the optimistic version of what happens after suffering a collapse of one's usual worlds of meaning; it has nothing to say about the difficulty or impossibility of interpreting oneself, of entering a new paradigm of self-narration (or about the outright refusal to partake in narrative self-interpretation, like the episodic individuals described by G. Strawson. $)^{21}$

18 On the limits of self-narrative in the light of psychoanalysis, see Jérôme Porée, "La philosophie au miroir de la psychanalyse", Laval théologique et philosophique, Volume 65, n³ (2009), pp. 405-429.

19 P. Ricœur, Temps et récit, tome 3, Paris: Seuil, 1991.

20 J. Michel, "Narrativité, narration, narratologie", Revue européenne des sciences sociales, t.XLI (2003) n ${ }^{\circ} 125$, pp. 125-142 and Sociologie du soi, Rennes: Presses universitaires de Rennes, "Sens social”, 2012.

${ }^{21}$ G. Strawson, “Against Narrativity”, Ratio (new series), XVII 4 (2004), p. 428-452. 


\section{The social and cultural conditions of interpretation and self- interpretation}

A phenomenology-based framework is still a very valuable resource for channeling our thoughts about the ordinary mechanisms of self-interpretation, including their failures. But this epistemological framework is not sufficiently sensitive to the social and cultural conditions that govern the act of interpreting, whether performed by individuals or by groups. Even in the most intimate relationship to oneself, in the most reflexive corner of self-interpretation, there is always an element of the social and cultural, largely overlooked by an entire phenomenological tradition inherited from Husserl, including that of Romano. For that reason, we prefer to use a framework inspired by the socio-phenomenology of Schütz ${ }^{22}$, a fertile current of thought that we try, at the same time, to combine with certain practices of structural analysis, though without espousing all of the implications of structuralism.

Despite all the individual variations, it would be a mistake to see interpretation, including self-interpretation, as being free from all constraints and predispositions. Indeed, nothing could be further from the truth. Social and cultural anthropology teaches us just how important are the symbolic frameworks, forms and structures by which we give meaning to the world, to others and to ourselves. It makes sense, then, to start out from the Kantian legacy of schematism, revisited both by the philosophy of symbolic forms, initiated by Cassirer, and by an anthropological tradition that runs from Lévi-Strauss to Descola.

The whole point of using schematism in structural anthropology is to extrapolate the schema as a representation of a class of situations, a representation that enables subjects to act in an orderly way whenever they are faced with analogous situations. Like Durkheim before him, Lévi-Strauss sought to "sociologize" the Kantian schemata ${ }^{23}$, while maintaining the idea that such an operation remains an "art hidden in the depths of the human soul". Lévi-Strauss pushes this perspective to its logical conclusion by locating schematism in the structural unconscious, along with the elementary structures of kinship which, like a system of linguistic signs, cannot be modified without redefining a whole set of oppositions.

22 Alfred Schütz, Collected papers. Studies in social theory, NYC: Springer, 2004. Schütz's socio-phenomenology aims to combine the sociology of Max Weber and Husserl's phenomenology. The central idea is to describe the world of social life as typified behavior.

23 Claude Lévi-Strauss, Anthropologie structurale, Tome 1, Paris: Pocket, 2003. 
This finally brings us back to the realm of the "savage mind (pensée sauvage)" 24 and to its hypothetical universality. For Lévi-Strauss, recognizing the cultural diversity of symbolic systems is not incompatible with the existence of a fundamental structure of the human mind. These partly innate dispositions can best be assimilated to the receptor structures ("structures d'accueil"), which enable the child to react to stimuli from its environment. These receptor structures, as potential schemas of practice, can only be filled, enriched and oriented through contact with the symbolic systems in place in every society.

Following Philippe Descola, one can distinguish between cognitive schemas that are assumed to be natural and universal, and cognitive schemas that are acquired through contact with cultural systems. Among the former - although this continues to be debated among biologists and psychologists - one would include schemas covering expectations about human actions (ascribing intentions to others), covering the mode of being of physical objects, and covering the nature of non-human organisms. Anthropology, however, focuses on collective schemas that serve to construct culturally shared meanings: "first, to structure the flow of perception in a selective fashion, granting a preeminence in signification to particular traits and processes that can be observed in the environment; second, to organize both practical activity and the expression of thoughts and emotions in accordance with relatively standardized scenarios; and third, to provide a framework for typical interpretations of patterns of behavior and events-interpretations that are acceptable and can be communicated within a community in which the habits of life that they convey are regarded as normal." 25

What does schematism-revisited by structural anthropologyteach us about interpretive and self-interpretive activity? Cultural schematism principally comes into play in any form of immediate understanding of symbolic or natural worlds: cultural schemas define the frameworks by which we identify ourselves, narrate ourselves, categorize ourselves, classify ourselves, and make clear to ourselves the distinctions between natural beings, social beings, and artificial objects.

When cultural schematism operates in ordinary, non-problematic situations, it is indeed a meaning-giving activity, but one that we might call proto-interpretive or pre-interpretive. This is the case with the collective

\footnotetext{
24 Claude Lévi-Strauss, La pensée sauvage, Paris: Agora, 1962.

25 Philippe Descola, Beyond Nature and Culture, Chicago: University of Chicago Press, 2014, p. 103.
} 
schemas that Descola rightly calls "non-reflexive", which can equally be compared to Charles Taylor's sensorimotor level of proto-interpretation, to Lévi-Strauss's pre-interpretive, pre-propositional level of classification systems in "pensée sauvage" and to Bourdieu's bodily knowledge, practical sense or habitus, i.e. embodied know-how, and the informed eye of savoir-voir.

When, however, individuals and groups are faced with distortions of meaning, and with the failure of their typical responses to the social or natural environment, a genuinely interpretive activity is required in order to restore continuity of meaning, resolve ambiguities, and resituate an event inside a symbolic system. Cultural schemas come into play at this reflexive level of interpretation. There are schematical cultural and social ways of dealing with the problematicity of the meaning of one's own existence in the process of self-interpretation. When we are faced with micro-distortions of meaning, the interpretive schemas that already exist are enough to restore continuity of meaning within a system of signifiers. In this case, the schematic operation is akin to Kant's "determinative judgment" in that it subsumes the disruptive event into a pre-existing schema. All it takes is a "makeshift" interpretation - a spot of interpretive "bricolage"- to integrate and recombine the events coherently into symbolic systems that ultimately undergo only minor modifications.

It is a very different configuration when individuals and societies are faced with a "problematicity of meaning" so extreme that it is totally incommensurate with pre-existing cultural schemas. For example: serious disruption of ecosystems; continual wars; political, economic and cultural revolutions; colonial invasions; and culture clashes that affect the way in which individuals and collectives interpret themselves. What we find here is a significant disconnect between the existing schemas and the new world order, a disconnect which reflects the sudden powerlessness of determinative judgment and the usual interpretation procedures. In the worst-case scenarios, the gap between schemas and worlds can persist, expand, and trigger the collapse of the interpretive process, or even the progressive destruction of cultural universes, as we have seen with so many animist or totemic societies, powerless to generate renewed meaning given the sheer magnitude of the disruptions affecting them. And even more so, as LéviStrauss demonstrated, in the case of societies whose predominantly synchronic structures are more sensitive to events.

In more favorable scenarios, by contrast, one can observe new schemas being invented in order to overcome a problematicity of meaning of unprecedented intensity - an operation rather like the role played by the 
imagination in "reflective judgment". This invention may take the path of a brand new combination of existing schemas, or of the translation and transposition of existing schemas into other cultural worlds in order to construct new schemas capable of adapting to new configurations of the world and of nature. Such is the magnitude of these changes of meaning that single individuals are incapable of producing new cultural schemas on their own; these schemas are, by nature, collective. Such is the magnitude of these changes of meaning that it is not any one particular cultural schema that proves to be unsuited, it is the whole range of schematic structures that make up a cultural universe. For example, the imposition and penetration of naturalism in the totemic world, via colonization, means that -in these societies - the non-human can no longer even be seen as the psychic and social continuity of the human. Here we are not far (were it not for his Eurocentric bias) from the narrower sense that Patočka gives to the problematicity of meaning, when the entire political, social and natural order is suspended and brought into question. In such historically rare cases, interpretation comes to the fore in its most reflective function.

When it is not defeated by the sheer magnitude of the collapse of meaning, when it manages to invent new schemas and to reconfigure cultural worlds of meaning in new ways, interpretation also serves to give them a history. A history that is not just that of everyday accidents in which the diachronic has only a minor impact on the synchronic, but another history, in which the destabilizing power of the diachronic totally subverts the coherence of the synchronic, reconfiguring it into a new symbolic structure. In this case, the self narrative interpretation is thought in the terms of a collective narrative interpretation. 


\section{List of references}

Abbot, Andrew, "From Causes to Events", Sociological Methods and Research, 20, pp. 428-455.

Bessin, Marc, "Le trouble de l'événement: la place des émotions dans les bifurcations", Bifurcations, Les sciences sociales face à l'événement (Marc Bessin, Claire Bidart \& Michel Grossetti, eds.), Paris: La découverte, 2010.

Descola, Philippe, Beyond Nature and Culture, Chicago: University of Chicago Press, 2014.

Dewey, John, Logic, Theory of Inquiry, NYC: Read Books, 2007.

Foucault, Michel, L'Herméneutique du sujet, Paris: Gallimard, 2001.

Heidegger, Martin, Etre et temps, Paris: Gallimard, 1992.

Hughes, Everet, "Cycles, Turning Points and Careers", The Sociological Eye, Aldine, Chicago (1971) pp.124-131.

Grossetti, Michel, Sociologie de l'imprévisible. Dynamiques de l'activité et des formes sociales, Paris: PUF, 2004.

Leclerc-Olive, Michèle, Le dire de l'événement, Lille: Presses du Septentrion, 1997.

Lévi-Strauss, Claude, La pensée sauvage, Paris: Agora, 1962.

- Anthropologie structurale, Paris: Pocket, 2003.

Mead Herbert, Georges, Mind, Self, and Society, Chicago: University of Chicago Press, 2015.

Michel, Johann, "Narrativité, narration, narratologie", Revue européenne des sciences sociales, t.XLI (2003) n¹25, pp.125-142

- Sociologie du soi, Rennes: Presses universitaires de Rennes, "Sens social", 2012.

Ogien, Ruwen, "Plaidoyer pour l'événement quelconque ", L'événement en perspective, Paris, Ed. EHESS (1991), pp.203-227

Patočka, Jan, Essais hérétiques, Paris: Verdier, 1990.

Pollak, Michael, L'Expérience concentrationnaire. Essai sur le maintien de l'identité sociale, Paris: Métailié, 2000,

Porée, Jérôme, "La philosophie au miroir de la psychanalyse", Laval théologique et philosophique, Volume 65, n³ (2009), pp.405-429.

Quéré, Louis \& Terzi, Cédric, "Pour une sociologie pragmatiste de l'expérience publique", SociologieS [online], Dossiers, Pragmatisme et sciences sociales: explorations, enquêtes, expérimentations, online since $23 \mathrm{Feb}$ (2015), consulted 12 Jan 2016. URL: http://sociologies.revues.org/4949.

Schütz, Alfred, Collected papers. Studies in social theory, NYC: Springer, 2004.

Strawson, Gelen, “Against Narrativity", Ratio (new series), XVII 4 (2004), pp. 428-452.

Strauss, Anselm, La Trame de la négociation, Paris: L'Harmattan, 1991.

Ricœur, Paul, Soi-même comme un autre, Paris: Seuil, 1990.

- Temps et récit, tome 3, Paris: Seuil, 1991.

Romano, Claude, L'événement et le monde, Paris: PUF, 1999.

- L'aventure temporelle, Paris: PUF, 2010.

Taylor, Charles, Sources of the Self, Harvard: Harvard University Press, 1992. 


\begin{abstract}
Interpretation is both a specific domain in the theory of knowledge (hermeneutics) and a technique suitable for use in the social sciences, and particularly in sociology. Interpretation can be applied to texts, actions and so forth. The aim of this presentation is to delve into the use of interpretation as a common, ordinary technique to establish a relationship with the world or with ourselves when we are faced with problematic, traumatic events. More specifically, we will focus on narrative as a specific type of common technique of interpretation used by individuals and groups seeking to inscribe shocking events into the story of their lives. However, for such a process to be possible, several conditions of possibility (both social and cultural) need to be met, and we will address these conditions in this presentation.
\end{abstract}

Key-words: interpretation - self - hermeneutics - narrative - event

\title{
RÉSUMÉ
}

L'interprétation est à la fois un domaine spécifique de la théorie de la connaissance (herméneutique) et une technique adaptée aux sciences sociales et particulièrement à la sociologie. L'interprétation peut être appliquée aux textes, aux actions, etc. Le but de cette présentation est de se pencher sur l'utilisation de l'interprétation comme une technique commune et ordinaire pour établir une relation avec le monde ou avec nous-mêmes lorsque nous sommes confrontés à des événements problématiques et traumatiques. Plus précisément, nous nous concentrerons sur le récit comme un type spécifique de technique commune d'interprétation utilisée par les individus et les groupes cherchant à inscrire des événements marquants dans l'histoire de leur vie. Cependant, pour qu'un tel processus soit possible, des conditions de possibilité (sociales et culturelles) doivent être satisfaites, et nous aborderons ces conditions dans cette contribution.

Mots-clés: interprétation - soi - herméneutique - récit - événement 